\title{
T. S. Eliot's 'Obscurity' in The Love Song of J. Alfred Prufrock
}

\author{
Longxing Wei \\ Department of Linguistics, Montclair State University \\ 1 Normal Avenue, Montclair, New Jersey 07043, USA \\ E-mail: weil@mail.montclair.edu
}

Received: 07-01-2016

Accepted: 05-04-2016

Published: 01-07-2016 doi:10.7575/aiac.ijalel.v.5n.4p.38

\author{
URL: http://dx.doi.org/10.7575/aiac.ijalel.v.5n.4p.38
}

Advance Access Published: May 2016

\begin{abstract}
T. S. Eliot's earliest verse is composed of observations, detached, ironic, and alternatively disillusioned and nostalgic in tone. Eliot's mingling of subtle observation with unexpected cliché represents a difficulty that is often magnified because too much 'obscurity' is assumed. This paper aims at clarifying the 'obscurity' by means of a stylistic analysis of the linguistic devices that the poet used to create "The Love Song of J. Alfred Prufrock" and its intended meaning. Adopting the concept of style as 'foregrounding', the idea that style is constituted by departures from linguistic norms, it analyzes the poem in terms of its lexical foregrounding, and adopting the concept of style as 'choice', the idea that style is constituted by choices of linguistic devices, it analyzes the poem in terms of its syntactic choices. It claims that it is the systematic foregrounding or violation of the norm of the standard which makes possible the poetic utilization of language. Without seeing foregrounding as a poet's linguistic device, there could be no poetry for the poet or no possible understanding of poems for the reader. It also claims that stylistically significant syntactic choices by the poet serve effectively the intended meaning.
\end{abstract}

Keywords: stylistic, linguistic, style, lexical, foregrounding, syntactic, symbolic, mental

\section{Introduction}

When "The Love Song of J. Alfred Prufrock" appeared in Harriet Monroe's "Poetry" magazine in 1915, it struck readers as an astonishingly dramatic monologue, whose character, tone and language are highly ironic, and unexpected. The monologue is ironic with a title promising a "love song" from the lips of Prufrock, a decidedly unromantic name. The first syllable of the very name Prufrock suggests the word "prude" without he final consonant, while a "frock' is a garment considered overtly formal by young people of Eliot's generation. The monologue is unexpected in that the first two lines seem to promise a romantic act and scene: "Let us go then, you and I. When the evening is spread out against the sky." However, the reader is instantly jolted by an unexpected unromantic simile in the third line: The evening is spread out like a patient etherized upon a table." The "you" of the poem does not seem to be Prufrock' ladylove but a confidante, in effect, the reader, who will accompany his on a visit to some sort of evening party. The reader visualizes a route through a shabby and dusty urban neighborhood on a foggy evening to a place where "women come and go/ Talking of Michelangelo." Prufrock has "an overwhelming question" to ask and is fearful that he will not be acceptable to women on such an occasion, whether a marriage proposal or a declaration of love. He is a middle-aged, thin, fussy and self-conscious bachelor, and he suspects that "they" will notice his balding head. He agonizes over the possibility of rejection and repeatedly rationalizes all the likely reasons for it. He realizes that he is such an insignificant man who has "measured out [his] life with coffee spoons." Prufrock is timid, ineffectual, and inarticulate, but he briefly fancies himself a heroic character, such as a beheaded John the Baptist, a Lazarus returned from the dead, and a Hamlet who can assert himself and win the admiration of the woman and her friends. However, he realizes that he can never be "Prince Hamlet" but "the Fool." To compensate for his failings, Prufrock wonders if he can walk on the beach and attract the attention of mermaids in the surf, but decides not to as he wakens from his reverie with a sinking sense of drowning in reality. All Prufrock can do is to remain a lonely and unhappy man.

Eliot's earliest verse is composed of observations, detached, ironic, and alternately disillusioned and nostalgic in tone. The title of his first volume "Prufrock and Other Observations" is significant, which immediately suggests the observer and an objective attitude. These observations are made to convey feelings rather than novel perceptions of the social scene, and they "make us from time to time a little more aware of the deeper, unnamed feelings which form the subtraction of our being, to which we rarely penetrate" (Grant, 1982, p. 10). Eliot's mingling of subtle observation with unexpected cliché represents a difficulty that is often magnified because too much 'obscurity' is assumed. Obscurity may come from confusion of ideas, involved thinking, or irrelevant association. Eliot is not obscure in any of these senses. In his reading of the poem, Lentricchia (1994) rejects the objectivity of the work at face value by arguing that it is "a poem of feeling and sensibility masquerading as an observation, [...] in rhythms that forecast a voice of search and longing" (p. 243). According to Lentricchia, Prufrock's vision goes beyond the constraints of the ordinary world, but he is obviously unable, and ultimately unwilling, to convey the full measure of this vision to anyone else but himself. 
There is one obscurity really existing in Eliot's poetry, which is caused by remote or unusual objects appearing unexpectedly or familiar objects moving rapidly. It is Eliot's own method of making him seem obscure where he is clear as daylight. This method is led by his constant aliveness, his mingling of very subtle observation with the unexpectedness of objects or things. Though his 'obscurity' "may bore his readers and sometimes wearies those whose appetite for life is less insatiable than his own" (Gardner, 1949, p. 86). The poet himself never seems capable of boredom in his observation of the realistic world. Eliot's "outward scene never exists for its own sake and the world which is being created from these sensory impressions and concrete objects is a world of emotional realities" (Drew, 1949, p. 33). The poet differs from others inly in his realistic and direct observation of the same environment and in his awareness of the boredom and plight. Eliot's "symbol-making instinct man's knowledge and experience of the outer and inner world were projected into direct sensuous embodiment, giving them life and outline and meaning, turning force into form" (Drew, 1949, p. 5). The reader will never arrive with Eliot at his meaning unless he follows the poet with the same nimbleness and straightness in seeing the reality in his mind. This is the basic but necessary starting point in reading Eliot's poetry.

From this starting point, this paper aims at clarifying Eliot's 'obscurity' by means of a stylistic analysis of the linguistic devices that the poet used to create The Love Song of J. Alfred Prufrock (hereafter The Love Song) and its intended meaning. Adopting the concept of style as 'foregrounding', the idea that style is constituted by departures from linguistic norms, we may analyze the poem in terms of its lexical 'foregrounding', and that of style as 'choice', the idea that style is constituted by choices of linguistic devices preferred by the speaker or writer, we may analyze the poem in terms of its syntactic choices. The basic claim of this paper is that it is the systematic 'foregrounding' or violation of the norms of the standard which makes possible the poetic utilization of language. Without seeing 'foregrounding' as a poet's linguistic device, there could be no poetry for the poet or no possible understanding of poems for the reader. The other basic claim of this paper is that stylistically significant syntactic choices by the post serve effectively the intended or plausible meaning of the poem.

\section{Lexical Foregrounding}

Halliday (1971) defines 'foregrounding' as "prominence that is motivated" (p. 339). According to him, stylistically speaking, the predominance of certain kinds of structures and grammatical categories deviates from the norms of the standard language. Such a deviation is a motivated phenomenon in that it constitutes part of the meaning of a literary work. A linguistic norm may be set up within a work itself but then is internally broken as is often the case in poetry. Foregrounding is often claimed to be a defining feature of literature (Miall \& Kuiken, 1994).

The notion of unexpectedness or unconventionality that is explicit in foregrounding theory is motivated by the mathematical information theory as originated by Shannon (1948), which gains popularity outside its intended domain of communication engineering. Researchers have been attempting to apply information theory to literature to demonstrate that poetic devices like foregrounding make literary texts richer in content than ordinary, utilitarian texts. Shklovsky (1917) argues that foregrounding refreshes perception but, because the effect of all poetic devices wears off as readers get accustomed to them, literature needs to constantly refresh perception by introducing new foregrounding devices. Similarly, Van Peer at al. (2007) views the role of foregrounding as inviting audiences to interpretation by slowing them down and forcing them to think the text over. As assumed, foregrounding importantly evokes feelings, personal perspectives and memories. On the other hand, present in the notion of foregrounding is also the idea that deviated, striking turns of linguistic expressions must at some level be apt and uniquely fitting the purpose to evoke the sense of necessity in the reader. Thus, Mukařovský (1964) points out that foregrounding has the systematic character that all the elements in the poetic text work in the same direction. Berlyne (1960) also writes about such an aptness in terms of a "subtle property [...] when an element is appropriate for several different reasons at once" (p. 254). According to these scholars, without this aptness, foregrounding would be purposeless and the foregrounded passage would be pointless or even absurd. Garner (2001) emphasizes that poetic devices like foregrounding must help convey meaning; otherwise, they become an obstacle.

It is believed that in any discourse, including poems, lexical choice is intimately associated with, and partly limited by, choice of subject matter. What is at issue here is that lexical choices which result most directly from choice of subject matter are likely to be the least striking stylistically, but, instead, lexical foregrounding may show the poet's stylistic preference to match his subject matter to the extent that it is likely in a specific poetic context (cf. Aitchison, 1994; Carter \& Walter, 1990). Mandel (1998) argues that "The selection of the right or best word or phrase in the right or best place is so delicate a task because - the exaggeration is minute - there are no synonyms" (p. 192). The following is an attempt to analyze the lexical foregrounding aspect of Eliot's style in terms of the subject matter that he intends to express in The Love Song.

\subsection{Words: things, oppositions and reality}

The Love Song deals with the reactions of an individual to a situation for which his own character is responsible, and in turn this makes it idiosyncratic, or obscure as often considered, and thereby induces the attendant dangers of incomprehensibility. What is important here is how to catch the psychological subtlety of the poem by seeing Eliot's major strength: reality, stripped naked of all rhetoric, of all ornament, of all confusing and obscuring association. This reality is really what the poet is after and it is depicted through the words and phrases he chooses to show things standing in oppositions, which is his very wailing testament of the soul of the modern land. In this vision of the contemporary world, Eliot always remains true to the objects he portrays; his 'observations' are objective, and his vision, and Prufrock's, has its place in due setting if the reader is to believe its reality. In the poem, Eliot uses 
contemporary detail without confining himself neither to genre nor to society portraiture. Without seeing clearly Eliot's realism in The Love Song, one can hardly catch his psychological subtlety that he is intending to show to the intelligent reader (cf. Lakoff, 1987; Kempson, 1988; Lakoff \& Turner, 1989).

What Eliot does in a great deal of The Love Song is to discover a relationship between items ordinarily thought of as completely disparate. The relationship may even be one of strong tension, in which the materials pull against each other and resist any reconciliation. For example, Prufrock's sense of impotent inferiority or isolation are described by Eliot's means of various oppositions of certain particular objects or phenomena in reality, through which Prufrock's inhibition by the discrepancy between wishes and facts are vividly depicted. We may see in Figure 1 the comparison between the words and phrases that Eliot chooses to reveal such oppositions.

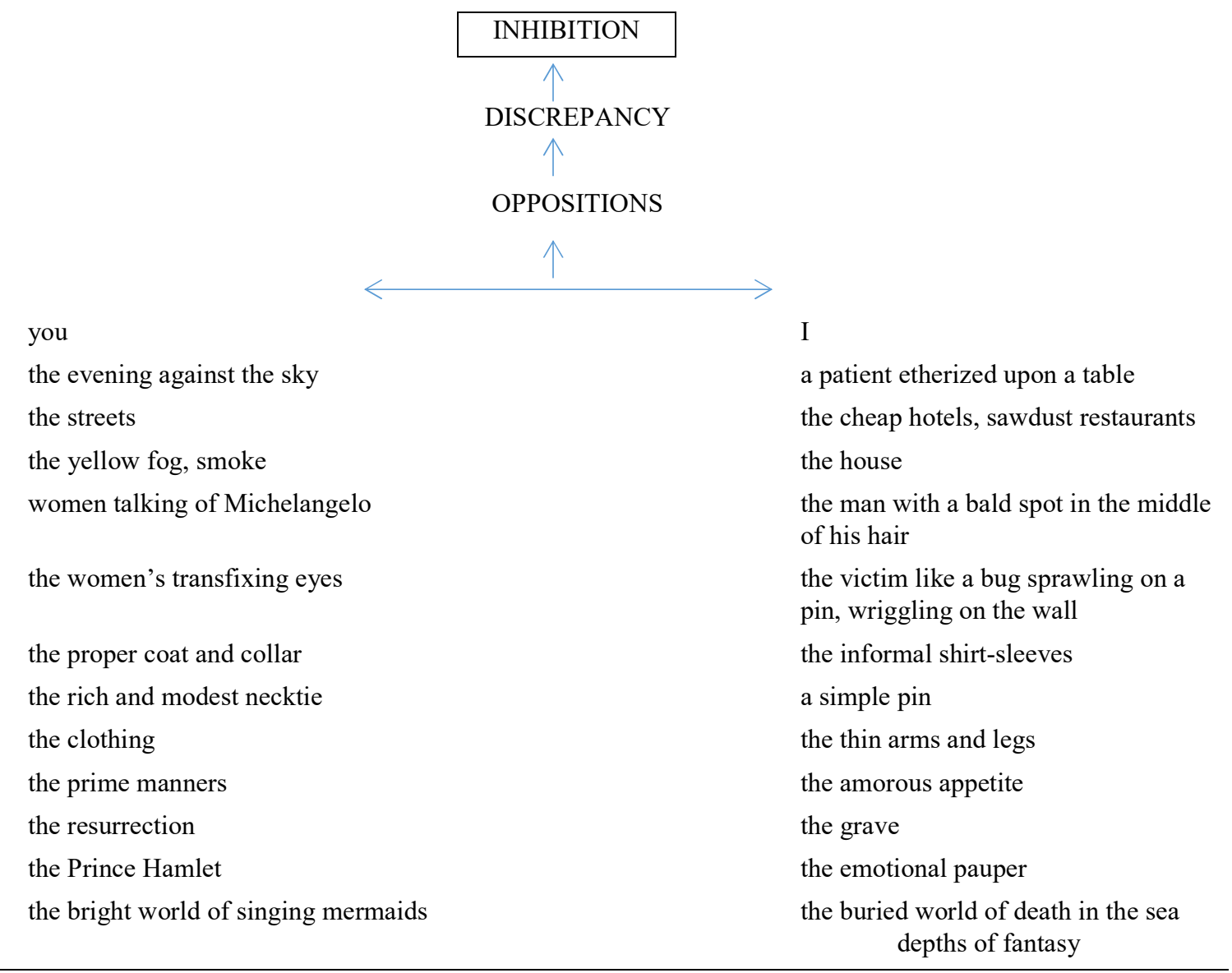

Figure 1

These things and oppositions, both physical and psychological, are constantly oppressing Prufrock, the speaker. Not only the reader's eyes but also the speaker's mind cannot avoid seeing these things in the poem.

There are certain things in the present that are evidently repugnant to Eliot as there are certain things in it are repugnant to most of us. But the issue is not the degree of enthusiasm that Eliot feels for the present day but rather his willingness to face up to the present reality and his ability to render it with honesty and conviction in the poem. If the ugliness is a part of the reality, it must not be glossed over or denied. If it is in effect denied, then the poet's deeper vision of reality will seem simply an imposed subjective interpretation, a vision that has not really been earned. His realities may be a modern street or a cheap section of town; it may be an ordinary human mind suddenly and fatally aware of what is happening to it; it is the stuff of our modern world, and true of more places than one. His street and his drawing-room are carefully presented as they are, and Prufrock's thoughts as they are. Eliot requires the reader to see these vivid realities in the ways as he sees them and "to be able to see beneath both beauty and ugliness; to see the boredom and the horror, and the glory" (Eliot, 1933, pp. 98-99).

\subsection{Words: symbolic images and mental states}

It is the means whereby Eliot finds the words to express his images which are of the utmost importance of this study of his literary style, for using words to realize symbolic images is the most significant part of his work. Let us just take a look at a line from The Love Song:

I have measured out my life with spoons 
Here is a precise image, which shows us the smallness and daintiness of the visual coffee-spoon measure, Prufrock's awareness of the smallness of bourgeois life as it was measured out to him. The whole of Prufrock is made up of similarly intensely felt 'surprise' images:

The yellow fog that rubs its back upon the window-panes

The yellow smoke that rubs its muzzle on the window-panes

Licked its tongue into the corners of the evening

Prufrock's daydreams dominate his transactions with reality. His love song "will never be uttered outside the inferno of his own mind, and the 'you and I' of his soliloquy" (Drew, 1949, p. 34) are his response to the reality that surrounds him. This is direct sensuous apprehension of his thoughts. Eliot does not wish to express the abstract thoughts of Prufrock. What he wishes to do is to present an uneasy state of mind, and so he correlates Prufrock with the evening and presents the resultant image in the form of a 'sense' image, visible and concrete.

With the image of the fog as cat we have the reflection of Prufrock's mental state: desire which ends in inertia. If the cat image suggests sex, it also suggests the greater desire of inactivity. Analogy between Prufrock and the evening is so condensed, so immediate that the two are identified. This single image, however, will not communicate all that Eliot wishes us to feel about Prufrock and so he takes more images, and the group together of the complex view of the world which Prufrock represents.

Prufrock has conceived the desperate idea of disturbing the universe. He is wondering

Do I dare

Disturb the universe?

The tension by raising the question of daring only particularizes his fear. The 'tension' image of climbing stairs, with its implication of effort, only exposes his weakness in the self-conscious disabilities proper to unromantic middle-age. As he goes downstairs he is aware of his futility, aware that the noticeable thing about him is the

Bald spot in the middle of my hair

He is self-conscious, introspective. He has an idea, an idea that he can put into action:

I shall wear the bottoms of my trousers rolled

But he is timid, incapable of any action more momentous, more disturbing. It is "the universe" of Prufrock himself which is the center of interest. His despairing introspective daydream and his mingled self-pity and self-disgust are presented to the reader's mind through the realistic images of "certain half-deserted streets" and "yellow fog".

It seems clear that Eliot does not use images as ornaments. The image itself is the speech. The image is the word beyond language (cf. Leech \& Short, 1981; Turner, 1987; Tannen, 1989; Toolan, 1988, 1990). Figure 2 lists some apparent words and phrases used in The Love Song (in the left column) to represent images showing Prufrock's psychological plight in his amorous discursions (in the right column).

\section{TRANSFERENCE}

\author{
Realistic objects or phenomena \\ (symbolic images) \\ you and I \\ the evening, the muttering retreats, \\ restless night \\ a patient etherized \\ streets like a tedious argument of \\ insidious intent \\ one-night cheap hotels and sawdust \\ restaurants \\ Michelangelo \\ the fog (cat) \\ time \\ the stair \\ a bald spot \\ thin arms and legs \\ the universe
}

\author{
Psychological portraits or revelation \\ (mental states) \\ mental confusion and emotional conflict \\ slow movement, mental inactivity \\ mental inactivity, paralysis \\ the plight of listlessness, lack of \\ purpose, boredom \\ social inferiority, sordidness \\ self-abased, inferiority complex \\ monotonous, mental inactivity, tardiness \\ lack of determination, indecision \\ contemplating a possible crisis of decision \\ self-pity and feeling of failure \\ self-pity and self-disgust \\ the whole inner self
}


coffee spoons measuring out life

sprawling on a pin

pinned and wriggling on the wall

lonely men in shirt-sleeves leaning

out of windows

a pair of ragged claws

the floors of silent sea

head upon a platter

being not Prince Hamlet

the Fool

the singing mermaids not singing to me

the chambers of the sea mental stagnation

unrest, listless, frustrated

uncomfortable and suffering

plight of listlessness, lack of

purpose, boredom

self-disgust and sheer panic, the longing for uncomplicated existence, acceptance of the hopelessness of struggle

a part of the living-death place where there is more freedom for self-desire

terror and timidity

incapability, cowardice, the timid self

stupidity

a living force that he lacks in his life

a part of the living-death place for a pitiful soul

Figure 2

Though the delicacies and strange nuances of The Love Song are superficially disordered or obscured, they are the profound realistic symbols used by Eliot for the purpose of psychological revelation. Eliot's objective and allusive method of finding resemblances between objects in reality and events in psyche may imply that the eternal truths are metaphors of reality that has come to occupy one's mind. His method of "perceiving inner realities through their reflection in concrete image, and all the disciplines which have to accompany its translation into language, was what Eliot was in particular 'battling to recapture' in the practice of poetry"' (Drew, 1949, p. 18).

If we take a brief look at some major lexical categories used in The Love Song, we may see the fact that language is the medium through which the quality of Eliot's thinking and feeling operates.

List 1: Lexical items

Adjectives: etherized, half-deserted, muttering, restless, cheap, tedious, insidious, overwhelming, asleep, bald, thin, simple, dying, downed, white and bare, narrow, lonely, ragged, silent, tired, afraid, impossible, politic, cautious, meticulous, obtuse, ridiculous, old

Nouns/Noun phrases: patient etherized on a table, half-deserted streets, muttering retreats, restless nights, cheap hotels, sawdust restaurants, tedious argument, insidious intent, yellow fog, yellow smoke, indecisions, visions and previsions, bald spot, simple pin, voices dying with a dying fall, butt-ends, narrow streets, ragged claws, crisis, Footman, Lazarus, the dead, the Fool

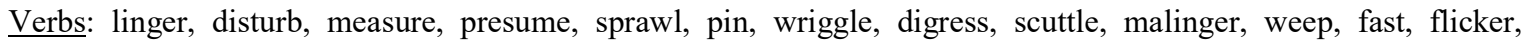
snicker, bite off, squeeze, drown

The modern poets like Eliot "asset their freedom from constraints of "poetical' language" with "an unprecedented audacity" (Leech, 1989, pp. 49-50), and "make use of the stylistic device of transposing pieces of ordinary, non-poetic language into a poetic context" (Leech, 1989, p. 59). From the lexical items and phrases in List 1, we may see that these words are used apparently in negative sense by the poet to describe and reveal Prufrock's psychological activity. The lexical items and phrases that Eliot borrows from registers of medical profession, marine world, religion, environmental pollution, commonplace, and absurd sociocultural behaviors are metaphorised and proverbialised to portray the feelings, situations and dimensions of modern life as visually observed, mentally perceived and behaviorally actualized by Prufrock. In other words, such lexical items and phrases from various registers not only defamiliarise and foreground the poetical text but also reveal the persona's psychological conditions and emotions. It should be clear that these lexical items and phrases from various non-poetic registers must be intentionally exploited by Eliot to propel the poetic discourse.

Nearly all the lexical deviations in The Love Song are metaphors. A metaphor consists of two domains: "source domain and target domain (Holme, 2004, p. 17). The source domain (the literal meaning) maps onto the target domain (the imaginative meaning). That is, metaphors create new meanings. During this mapping process an intelligent reader resorts to the imaginative meaning by abandoning the literal meaning. In general, metaphors and symbols replace direct statements in The Love Song. Impressions are strung along a tenuous thread of sense. A familiar situation: the hesitating amours of the middle-aged, the failure of a certain man to establish the expected relation with a certain woman, is given in Eliot's poetic monologue. "Things follow logically enough from the perceiver, his visit, and the room; but many connections in the poem are associative relations, not logical relations, and are established by the feeling, in which the association of images is an important factor" (Williamson, 1974, p. 67). The poet's objects and 'meanings' synchronize and are recognized simultaneously. The transitions are immediate and unexplained; the logic is the logic of images, no longer the commonly recognized pattern of discourse. 
Eliot does not care whether or not there is a logical association between these objects in the poem, but he never intends that the reader should infer that the object is the subject of his thoughts, instead that he should feel the particular emotion appropriate to what is objectified. As the oppositions of certain particular objects and transference from realistic objects to psychological portraits discussed above, the references in Eliot's many other comparisons in the poem are less to the things compared than to the mood, character, or situation with which they are associated. In the poem, the reader gets a glimpse of the visions and the tragedy that are in Prufrock's soul. His soul in the situation has to look out on streets, cheap hotels, sawdust restaurants, drawing-room, mermaids, or the sea. The reader sometimes overlooks the obvious and tries to catch the allusions in the larger context of the poem as a whole. This is because the poet's allusions are erudite, oblique, and obscure, in which he clothes the emotions he wishes to express. Thus, to understand his meaning, the reader must look into the poet's mind since his subject is always the ingredients of the modern mind. In other words, in reading Eliot, the reader's imaginations are put at no loss by the change of symbols. Such a change of symbols, or of objects or phenomena, of course would not be real if there were no poetic message transmitted (cf. Turner, 1987). It is just by this approach with the change of symbols that the poem does record in Prufrock himself a defeat of poetic power and so considerably qualifies the pathos of Prufrock's lament and expresses effectively the mental war between the desire for individuality and the doomed need for self-surrender.

\section{Syntactic Choices}

Jakobson (1987a) believes that poets always have the conviction that nothing can be left to chance in poetry because a poem must contain structures that are connected with its literary function and impact. Jakobson (1987b) claims that the poetic meaning can only be expressed by its particular form. Thus we arrive at the notion of convergence, to the point of identity and between form and content in poetry. Jakobson defines the language's poetic function as the orientation of the message towards itself. Likewise, Lotman (1994) specifically points out that all elements of the poetic form actually become semanticized to serve as vehicles of meaning, that is, a particular form in literary text will carry a particular meaning. Thus, in addition to the lexical foregrounding device, The Love Song can also be analyzed in terms of its stylistically significant syntax to see how Eliot chooses certain types of sentences and tense, aspect, and mood marking to accomplish psychological portraits (cf. Turner, 1987; Kempson, 1988; Carter \& Walter, 1990).

\subsection{Sentence types}

Two types of sentence are particularly chosen by the poet: interrogative and negative. Interrogative sentences (List 2) are exploited to show Prufrock's mental confusion, emotional conflict, plight of listlessness, lack of purpose, self-pity, lack of determination, and cowardice. Negative sentences (List 3) are exploited to show Prufrock's incapability, cowardice, the timid self, and lack of confidence.

List 2: Interrogative sentences

'What is it?'

To wonder, 'Do I dare?' and 'Do I dare?'

Do I dare

Disturb the universe?

So how should I presume?

Then how should I begin

To spit out all the butt-ends of my days and ways?

And how should I presume?

Is it perfume from a dress

That makes me so digress?

And should I then presume?

And how should I begin?

Shall I say ..., learning out of windows?

Should I, after tea and cakes and ices,

Have the strength to force the moment to its crisis?

And this, and so much more?

Shall I part my hair behind? Do I dare to eat a peach?

List 3: Negative sentences

Oh, do not ask, 'What is it?'

I am not prophet - and here's no great matter

'That is not it at all,

That is not what I meant, at all.'

It is impossible to say just what I mean!

No! I am not Prince Hamlet, nor was meant to be

I do not think they will sing to me

In addition to such interrogative and negative sentences, Prufrock's repetitions of "Do I dare?"; "how should I presume?"; "I have known them all" reveal his anxieties. He also repeats the answer he expects from the woman if he ever does succeed in making his declaration of love to her: "That is not what I meant at all; That is not it, at all." Like other features of the poem, these repetitions appear at irregular intervals. It is apparent that Eliot makes such syntactic choices with a definite purpose in mind. Prufrock asks himself so many questions that he himself cannot possibly 
answer, and on most occasions, that he dare not to answer. Prufrock's hesitation, indetermination, stupidity, timidity, and other fatal weaknesses are clearly shown to the reader. We may see that the poet's intentional syntactic choices cannot simply be made for the grammar itself, but such chosen sentence types themselves embody the meaning that the poet intends to convey. In the same manner, the negative sentences, also uttered by the unfortunate Prufrock himself, reinforces his self-pity and feeling of failure.

\subsection{Tense, aspect and mood}

The simple future tense (List 4), indicating a simple future activity or action, is exploited by the poet to show Prufrock's decisions and indecisions or visions and revisions. Prufrock always sees that there will be time for his actions, but such actions cannot be performed by himself, a timid, indecisive, useless person.

List 4: Simple future tense

And indeed there will be time

There will be time, there will be time

To prepare a face to meet the faces that you meet

There will be time to murder and create

And there will be time

To wonder

Time to turn back and descend the stair

In a minute there is time

For decisions and revisions which a minute will reverse

Am an attendant lord, one that will do

I shall wear the bottoms of my trousers rolled

I shall wear white flannel trousers, and walk upon the beach

The infinitive (List 5) plays its grammatical function to indicate specific physical action or mental activity. Used together with the simple future tense, the infinitive is used to show that Prufrock has many actions to take, but unfortunately he cannot possible perform such simple actions. This again shows that Prufrock is a timid, incapable man.

List 5: Infinitive

To prepare a face to meet the faces that you meet

to murder and create

To wonder, 'Do I dare?' and, ...

to turn back and descend the stair

To spit out all the butt-ends of my days and ways?

To force the moment to its crisis?

To have bitten off the matter with a smile

To have squeezed the universe into a ball

To roll it toward some overwhelming question

To say: 'I am Lazarus, ...'

To smell a progress, start a scene or tow

The perfect aspect (List 6) is greatly exploited by the poet, particularly with the verbs 'know', 'see' and 'hear', repeated time and again. The perfect aspect is used to indicate that Prufrock can have done nothing more active in his life experience, but only "have known", "have seen", or "have heard" something. The actual activities that Prufrock personally has actually done are those "have measured out my life with coffee spoons", "have gone at dusk through narrow streets and watched smoke", and "have lingered in the chambers of the sea". He is so confused, listless, indeterminate, and inactive that he can never accomplish anything more challenging for his own benefit.

\section{List 6: Perfect aspect}

For I have known them all already, known them all

Have known the evenings, mornings, afternoons

I have measured out my life with coffee spoons

And I have known the eyes already, known them all

And I have known the arms already, known them all

I have gone at dusk through narrow streets

And watched the smoke... 
Though I have seen my head [grown slightly bald]

I have seen the moment of my greatness flicker

And I have seen the eternal Footman hold my coat

I have heard the mermaids singing

I have seen them riding seaward on the waves

We have lingered in the chambers of the sea

The subjunctive mood (List 7) is used for hypotheticals or counterfactuals, which is exploited by the poet to reveal Prufrock's psychological activity. Hypotheticals may express unlikely yet possible events, but counterfactuals express impossible events or states. Quite a lot of counterfactuals, some of which are repeated time and again, are used in such an effective way that the reader may easily see that Prufrock can in fact accomplish nothing whatever.

List 7: Subjunctive mood

I should have been a pair of ragged claws ...

And would it have been worth it, after all

(repeated)

Would it have been worth while

(repeated three times)

If one, setting a pillow by her heard,

Should say: ...

If one, ... should say: ...

(repeated)

The above may show us that Eliot's choices of tense, aspect, and mood are made on purpose. These linguistic devices are exploited by the poet to the effect that they help to display Prufrock's psychological inner self.

\section{Conclusion}

The Love Song is a dramatic monologue. Prufrock utters a speech that implies his personal story and psychology and reveals his character. The implication of the poem is fairly clear and the revelation is fairly simple, but the full appreciation of the poem must to some extent depend upon the reader's responsibility for filling in what is unsaid. The so-called 'obscurity' is caused by the events that are not explicitly or fully indicated in the poem and, more importantly, the continuity or connectedness of the images is not clear. What may also make the reading of the poem difficult is that at first glance the transitions in Prufrock's utterance are violent and illogical or unjustifiable, and one thing unpredictably suggests another in the flow of consciousness. But how can the reader make sense of them? Is The Love Song a mere jumble of obscurity?

It is no mere jumble of obscurity, for the reader who may be obscured superficially can get a general impression of Prufrock. He is a middle-aged, somewhat over-sensitive and timid man, yearning and procrastinating, fearful that life has passed him by and yet somehow resigned to the fact. He is very much a creature of his world of drawing rooms and yet feeling vaguely dissatisfied with that world. But only a closer inspection of Eliot's stylistic devices will give us the full significance of many details in the poem and permit us catch the allusions and implications of the poem.

This stylistic analysis aims at showing how Eliot uses particular lexical and syntactic devices to make his poetics not less but more meaningful. Indeed, Eliot's poems often present formal difficulties of a much more discouraging nature, often seeming not to make sense, sometimes emotionally incoherent. However, his connections and transitions are visual and psychological rather than verbal of grammatical, where connectives are not written out in the narrative method, but, instead, poetic symbols are held together by the tension of their inter-relationships which are indivisible.

Eliot says that "The only way of expressing emotion in the form of art is by finding an 'objective correlative'; in other words, a set of objects, a situation, a chain of events which shall be the formula of that particular emotion" (Eliot, 1951, p. 145). This is an attempt to build a poetic structure out of the suggestive aspect of language alone, where the poet abandons a rational structure altogether and moves in a dislocated, stream-of-consciousness-type progression from image to image with little or no connection between them. Thus, the obscurity or 'unreasonableness' of the images and the disconnection between these images in The Love Song are in effect Eliot's outstanding stylistic device.

What is meant by saying that words become symbols is that Eliot's observation becomes poetic symbols. His 'objective correlative' may not only mean that the subjectivity is projected into the objective, but that objects become symbols, and such symbols are used by the poet as a particular kind of feeling in The Love Song.

The stylistic analysis of the words and phrases used in the poem as poetic symbols to present the poet's psychological observation may help us to clarify the so-called 'obscurity' of the poem. What becomes important is that Eliot's psychological observation translates imaginative symbols carried by words into psychic symbols and substitutes meanings qualified by emotion or feeling for those defined by the poem. The reader is "expected to recognize a world which is like the world we ordinarily call real. But illusion implies a reality; and reality lies behind the shadow world of illusion and deceit ..." (Ward, 1973, p. 13). The 'meaning' is the synthesis which the reader will be able to make, for 
here Eliot is working in a complex of associations which, by their vivid and concrete nature, enables us to see a constant value. But the meaning will not be a constant, and it will vary for each reader according to the value he gives to the connotation within the boundaries as fixed by the poet. But the reader will be obscured and lose the meaning of the poem if he cannot catch the connotations of each of the poetic symbols or images presented by the words and phrases within their psychological context. It is in this sense that we may say that some lexical items are 'foregrounded' by the poet to make symbols, create images, and convey the meaning. Without such a possibility of foregrounding, there would hardly be any poetry (cf. Weber, 1996).

In addition, the analysis shows that syntactic choices, together with choices of tense, aspect, and mood, made by Eliot are stylistically significant in the sense that they serve effectively to accomplish the subject matter, the intended meaning of The Love Song. In other words, the basic functions of certain syntactic structures or sentence types, and also the grammatical features of tense, aspect, and mood, can be exploited for stylistic purposes.

This analysis does not attempt to lay down any fixed rule for the permissible difficulty of obscurity or allusions. It is only focused on some stylistically significant linguistic devices adopted by Eliot. Though it is limited in its scope, it is hoped that it has proved to a certain extent that such an analysis is one of the effective ways of showing a poet's stylistic choices so as to understand and appreciate the poetic message or meaning most probably intended by the poet.

\section{References}

Aitchison, J. (1994). Words in the mind: An introduction to the mental lexicon. Cambridge: Blackwell.

Berlyne, D. E. (1960). Conflict, arousal, and curiosity. New York: McGraw-Hill Book Company.

Carter, R., \& Walter, N. (1990). Seeing through language: A guide to styles of English writing. Oxford: Blackwell.

Drew, E. (1949). T. S. Eliot: The design of his poetry. New York: Charles Scribner's Sons.

Eliot, T. S. (1933). The use of poetry and the use of criticism. London: Faber and Faber.

Eloit, T. S. (1951). Selected essays. London: Faber and Faber.

Gardner, H. (1949). The art of T. S. Eliot. London: The Cresset Press.

Garner, B. A. (2001). Dictionary of American Usage and Style. New York: Oxford University Press.

Grant, M. (Ed.) (1982). T. S. Eliot: The critical heritage Vol. 1. London: Melbourne and Henley.

Halliday, M. A. K. (1971). Linguistic function and literary style: An inquiry into the language of William Golding's The Inheritors. In S. Chatman (ed.), Literary style: A symposium (pp. 330-365). London and New York: Oxford University Press.

Holme, R. (2004). Mind, metaphor and language teaching. New York: Palgrave Macmillan.

Jakobson, R. (1987a). "Post scriptum" to questions de poetique. In R. Jakobson (ed.), Raboty po poetike [Works on poetics] (pp. 80-95). Moscow: Progress.

Jakobson, R. (1987b). Linguistics and poetics. In R. Jakobson (ed.), Language in literature (pp. 62-94). Cambridge: Belknap Press.

Kempson, R. M. (Ed.) (1988). Mental representations. New York: Cambridge University Press.

Lakoff, G. (1987). Women, fire, and dangerous things. Chicago: The University of Chicago Press.

Lakoff, G., \& Turner, M. (1989). More than cool reason: A field guide to poetic metaphor. Chicago: The University of Chicago Press.

Leech, G. N. (1989). A linguistic guide to English poetry. Hong Kong: Longman.

Leech, G. N., \& Short, M. H. (1981). Style in fiction: A linguistic introduction to English fictional prose. London: Longman.

Lentricchia, F. (1994). Modernist quartet. New York: Cambridge University Press.

Lotman, Y. M. (1994). Lekcii po struktural'noj poetike [Lectures on structural poetics]. In A. D. Koshelev (ed.), Y. M. Lotman I tartusko-moskovskaia semioticheskaria shekola [Y. M. Lotman and the Tartu-Moscow Semiotic School] (pp. 11-246). Moscow: Gnozis.

Mandel, O. (1998). Fundamentals of the art of poetry. Sheffield: Sheffield Academic Press.

Miall, D. S., \& Kuiken, D. (1994). Beyond text theory: Understanding literary response. Discourse Processes, 17(3), 337-352.

Mukařovský, J. (1932). Standard language and poetic language. In P. L. Garvin (ed.) (1964), A Prague School reader on esthetics, literary structure and style (pp. 17-30). Washington, DC: Georgetown University Press.

Shannon, C. E. (1948). A mathematical theory of communication. Bell System Technical Journal, 27(3), 379-423.

Shklovsky, V. (1917). Art as device. In L. T. Lemon and M. J. Reis (eds.) (1965), Russian formalist criticism: Four essays (pp. 3-24). Lincoln: Nebraska University Press. 
Tannen, D. (1989). Talking voices: Repetition, dialogue, and imagery in conversational discourse. New York: Cambridge University Press.

Toolan, M. J. (1988). Narrative: A critical linguistic introduction. London: Routledge.

Toolan, M. J. (1990). The stylistics of fiction: A literary linguistic approach. New York: Routledge.

Turner, G. W. (1987). Stylistics. New York: Viking Penguin.

Van Peer, W., Hakemulder, J., \& Zyngier, S. (2007). Lines on feeling: Foregrounding, aesthetics and meaning. Language and Literature, 16(2), 197-213.

Ward, D. (1973). T. S. Eliot between two worlds: A reading of T. S. Eliot's poetry and plays. London: Routledge and Kegan Paul.

Weber, J. J. (Ed.) (1996). The stylistics reader: From Roman Jakobson to the present. Bew York: Arnold.

Williamson, G. (1974). A reader's guide to T. S. Eliot. New York: Octagon Books. 